\title{
Influence of Sustainable Hospitality Supply Chain Management on Customers' Satisfaction and loyalty
}

\author{
Mohamed abu Taleb Mohamed \\ , Abd El-monem Omar Mohamed ${ }^{\mathrm{b}}$, \\ Hamada Anwer Hamed Elkashak ${ }^{c}$, \\ ${ }^{a}$ Professor, Hotel Studies Department, Faculty of Tourism and Hotel, University \\ of Sadat City \\ b Associate professor, Hotel Studies Department, Faculty of Tourism and \\ Hotels , University of Sadat City \\ ${ }^{\mathrm{c}}$ Demonstrator at Alson Higher Institute for Tourism and Hotels, Nasr City
}

\section{Keywords}

Sustainability

Supply Chain

Hospitality

Customer Satisfaction

Customer Loyalty

\begin{abstract}
This study aims to identify the impact of the environmental, social, and economic dimensions of sustainable hospitality supply chain management actions on customer satisfaction and loyalty for sustainable hospitality goods and services utilizing data collected from Cairo consumers who frequently stay at hotels. To achieve the purpose of this paper a questionnaire is developed by $\mathrm{Xu}$ and Gursoy's (2015a). 563 questionnaire forms were distributed to a random sample technique of customers in Five-star hotels in Cairo, while508 questionnaires were recollected with an approximate response rate of $91.2 \%$ of the total sample and were found usable for analysis. The correlation between all dimensions of sustainable hospitality supply chains (social - economic environmental) and customer satisfaction were strongly and positively. Also, there is a positive relation between the three dimensions of sustainability and customer loyalty, and there is also a very strong positive relationship between customer satisfaction and loyalty.
\end{abstract}




\section{Introduction}

Sustainability issues have been receiving increasing attention from both practitioners and researchers in the hospitality industry in recent years (Berezan et al., 2013). One of the reasons for this increase is that an increasing number of travelers pay close attention to the sustainability actions of companies (U.S. Travel Association, 2009) and hold positive attitudes towards companies implementing sustainability actions (Xu and Gursoy, 2015).Sustainability practices have become one of the most important factors influencing customers' perceptions and decision-making processes (Berezan et al., 2013). Studies suggest that sustainability practices have become significant determinants of customer satisfaction and loyalty (Teng et al., 2012).

While several studies have examined the sustainability practices of the hospitality business and the impacts of those practices on travelers buying behaviors (Teng et al., 2012), most of the previous studies have only focused on one dimension of sustainability such as the environmental aspect including environmental management and green practices (e.g., Rahman et al., 2012), or social aspect such as corporate social responsibility (e.g., Paek et al., 2013).

\section{Literature Review}

\subsection{Hospitality Supply Chain Management}

Although several researchers have studied problems related to different facets of the hospitality supply chain, the whole hospitality supply chain is rarely discussed (L. M. Tsai, 2012).X. Zhang et al. (2009) and Huang et al. (2012) are among the few researchers who examined the tourism supply chain framework. X. Zhang et al. used a supply chain framework to identify and discuss the critical issues including demand management, stakeholders' relationships, supply and inventory management.

Afterward, Huang et al. (2012) analyzed tourist demand quantity, competition among partners in the tourism supply chain including travel agents, tour operators and hotels. However, these studies mainly examined the tourism supply chain in the form of a distribution system that focuses on the distribution of tourism products to tourists while collaborating with companies in the system.

A hospitality supply chain (HSC) is defined as a network of hospitality organizations engaged in various activities including the supply of various components of hospitality products and/or services 
such as raw material, equipment and furniture from various providers; distribution and marketing for the hospitality products and/or services to the customers for a specific hospitality business such as a hotel or a restaurant.

\subsubsection{Characteristics of hospitality supply chain Management}

The hospitality supply chain delivers both products and services from initial suppliers to customers with a value incremental process (Kothari et al., 2005). It incorporates the characteristic of both the manufacturing and service supply chain. Because of unique characteristics of the hospitality industry, the hospitality supply chain has six Characteristics that differentiate it from a traditional supply chain.

First, most of the hospitality products are perishable; while some products are physically perishable for example foods, which are normally expired in a few days, others such as some unsold products (e.g., hotel rooms) cannot be kept in inventory for sometimes later. Since the contribution of each room sold to organization profit is considerable, while the unit variable cost of the room is much lower than the high fixed cost (Guo et al ., 2013), revenue management, which aims to achieve the maximal income, is of the utmost importance for the midstream suppliers such as hotels in a HSC.

Second, for the services, the generation of customer demand is important. Good communication, on-time services, friendly attitude are among the key factors in services to create positive word-ofmouth and, therefore, ultimately generate demand in HSC given that the hospitality industry is a very interactive industry (Cantallops et al., 2014; Šreri'c et al., 2012).

Third, there are different suppliers in a HSC due to the complex nature of products and services provided to customers. For instance, waste recycling and disposal being performed by initial suppliers (Huang et al., 2012). They deal with products that might never again require or are used through reverse logistics. Therefore, HSC incorporates some features of closed-loop supply chains.

Fourth, the demand for products and services in HSC is highly uncertain and complicated because of the dynamic nature of the industry for two reasons. First, there is intense competition among different hospitality businesses that provide heterogeneous and compound products and services. Second, external factors for example, seasonal factors, macro and micro economic conditions, and even weather could influence the demand (X. Zhang et al., 2009). 
Fifth, hospitality guests, who are the main customers, often need to travel to the physical place of hospitability businesses to consume these products and services. Therefore, logistics usually happens between initial suppliers and hospitality businesses but not among hospitality businesses and customers. Customers can evaluate the products and services in HSC only after they purchase and consume them in a physical location like a hotel or a restaurant.

Lastly, multiple hospitality products and services, which might be offered by various associations, are usually joined into a package offered to customers. In this manner, contracting and cooperation among various businesses in HSC are crucial. Effective management of a supply chain can enable hospitality businesses to deliver high-quality products and services consistently to their guests and keeping their costs down (Odoom, 2012).Since most hospitality businesses operate in a very competitive environment (Tse, 2009), effective supply chain management could bring significant competitive advantages. HSC management integrates and coordinates logistics management, inventory management, information technology management, stakeholder relationship management, and procurement and distribution management (Odoom, 2012).

\subsubsection{Sustainable hospitality supply chain}

The most commonly accepted definition of sustainability is: "meeting the needs of the present without compromising the ability of future generations to meet their own needs" (Brundtland, 1987). As per the CSCMP (Council of Supply Chain Management Professionals 2013, p.191): "Corporate sustainability refers to efforts a company makes related to conducting business in a socially and environmentally responsible manner.

Sustainability elements including sustainable development, corporate social responsibility (CSR), stakeholder concerns, and corporate accountability." Many of the definitions are derived from the "Triple Bottom Line" (Elkington, 1997) concept. "Triple Bottom Line" is the most prevalent concept in the literature which considers sustainability at the intersection of economic, social, and environmental goals of a firm.

The economic dimension addresses that the economic needs of the stakeholders (customers, employees, suppliers, investors, etc.) are met effectively and efficiently, the social aspect is worried about human rights and employees' health and security, and the environmental aspect assures waste minimization, emission reduction and protection of natural resource depletion (Bansal et al., 2009; 
Krause et al., 2009). Triple Bottom Line is additionally for the most part called (3Ps): People, Profit, and Planet. The intersection of these three dimensions depicts the core of sustainability.

\subsubsection{Dimensions of sustainable supply chain management}

While researchers are becoming more aware of the complexity of sustainability in supply chain management and do not treat green aspects and sustainability issues interchangeably anymore, more attention should be given to a holistic view of sustainability in supply chain management.

Sustainability in supply chain vision implies the need for each member to fulfill social and environmental criteria (Seuring and Muller, 2008). Branderburg et al. (2014), in the analysis of a quantitative model for sustainable supply chain management, confirm the need to look further into social aspects to prevent them from becoming limitedly relevant.

The economic dimension is the easiest to measure and describe due to its quantitative nature. It refers to costs, profitability, revenues, and returns on investments. At a macroeconomic level, it regards gross domestic product, labor productivity, or import dependency (Branderburg et al., 2014).

Carter and Rogers (2008) explicitly mention the economic dimension as a sine qua non for any environmental and social initiative. The social dimension can be related to social well-being (Hassini et al., 2012) both at micro and macro levels. The first deals with the treatment of labor force, customers and sourcing practices, while the second evaluates the social impact of these practices on communities. Labor force management can be extended in the following aspects: wages, employment gender ratios, working conditions, investments in human capital, and child labor (Beske et al., 2014; Branderburg et al., 2014; Carter and Rogers; 2008). Hassini et al. (2012) summarized that socially responsible organizations engage only in labor practices that are considered ethical.

Environmental sustainability embraces environmental responsibility and environmentally friendly technologies (Winter et al., 2013). Environmentally friendly practices include reduced packaging, fuel-efficient transportation (Carter and Rogers, 2008), efficiently and environmentally friendly material sources, low carbon emission, energy-efficient machines (Hassini et al., 2012), green transport practices (Abbasi and Nilsson, 2012), renewable energy sources, water and energy consumption, waste management, and 
pollution (Branderburg et al., 2014).

\subsection{Customer Satisfaction}

Customer satisfaction can be defined as an evaluation resulting from the cognitive processes corresponding to a comparison between customers' experience and their initial reference base (Aurier and Evrard, 1998). The environmental dimension of sustainable hospitality supply chain management is likely to have positive influences on customer satisfaction (Berezan et al., 2013) because environmental conscious businesses would address both the economic and social interfaces within the natural environment and, therefore, be considered as a more balanced and complete organization.

\subsubsection{Impact of Sustainable Hospitality Supply Chain Management on customer satisfaction.}

The environment- friendly actions taken by a business could be seen as an integral part of a service offer and therefore, increases customers' overall satisfaction (Berezan et al., 2013). More specifically, since the hospitality industry is an energy-intensive, natural resource consumption, and waste generating in great quantities type of industry, it has always been under pressure from environmentalists and other grassroots organizations to become more environmentally friendly (Cetinel and Yolal, 2009). This pressure resulted in the adoption of certain environment-friendly initiatives to reduce the hospitality industry's "environmental footprint," which proved to be an effective way of increasing customer satisfaction (Prud'homme and Raymond, 2013). The customer tends to be more satisfied with companies that are engaged in relatively more environmental-friendly practices in the service delivery process compared to other companies (Gao and Mattila, 2014). Therefore, hotels' green practices are likely to have a significant impact on guests' satisfaction (Berezan et al., 2013).

The social dimension of sustainable hospitality supply chain management can also have positive influences on customer satisfaction. The socially responsible actions towards both internal and external stakeholders can enhance customer satisfaction. On the internal stakeholder side, customers nowadays are paying more attention to employees' welfare and working conditions (Costen and Salazar, 2011). Growing consumer backlash against companies because of the working conditions of employees is a clear indication of this trend (Knorringa, 2009). Companies that aim to be more socially responsible develop public corporate codes that describe 
employees working conditions, which integrate sustainability principles into various processes in a supply chain and ensure employees' acceptance and participation (Brown, 2007).

Enhancing employees' health and safety and offering training to them would not only increase the employees' job satisfaction but also enhance the level of customer satisfaction (Leaniz and Rodriguez, 2015). Previous studies report a direct positive relationship between customer satisfaction and employee satisfaction (e.g. Chi and Gursoy, 2009). This positive relationship is even stronger in industries where the frequency of customer and employee interaction is relatively high like the hospitality industry (Kassinis and Soteriou, 2003).

On the external stakeholder side, customer satisfaction can also be improved by businesses' socially responsible actions (Miles and Covin, 2000). Businesses' long-term relationships with channel partners in the supply chain can enhance its sustainability (Closs et al., 2011). The collaboration with suppliers can lead to less raw material consumption and waste associated with extending product life (Guide et al., 2003). These actions can positively influence customers' preferences for a company's products and their perceptions towards the business reputation (Creyer and Ross, 1997).

Local community-oriented business practices can also enhance customers' satisfaction since customers strongly prefer local products (Holmes and Yan, 2012).

The economic dimension of sustainable hospitality supply chain management also plays an important role in customers' satisfaction.

Customers usually consider businesses with good financial performance as offering high-quality products and services, which enhances their satisfaction (Lo et al., 2015). Businesses with good financial performances tend to have the capabilities to operate efficiently, offer better- and high-quality products and services, which are considered as key determinants of customer satisfaction (Sanchez-Fernandez and Iniesta-Bonillo, 2009). Also, businesses with good financial performance are able to attract capital through investors, and through lowering over-investment, lower underinvestment, or both (Biddel et al.,2009). Good financial performance contributes a firm's ability to offer and deliver high-quality products and services (Assaf et al., 2012; Loureiro and Kastenholz, 2011) and, therefore, increase customer satisfaction (Jung and Yoon, 2013).

Hypothesis 1 The environmental, social, and economic dimensions of the management of sustainable supply chains in 
hospitality institutions have a significant positive impact on customer satisfaction.

\subsection{Customer Loyalty}

\subsubsection{Impact of Sustainable Hospitality Supply Chain Management on customer loyalty.}

The environmental dimension of sustainable hospitality supply chain management positively affects customer loyalty (Lee et al., 2010). In the hospitality context, green actions can enhance customer loyalty through a strong green image of hospitality businesses and other businesses involved in the supply chain (Kassinis and Soteriou, 2003). Many hospitality businesses have been developing green positioning strategies in recent years (Lee et al., 2010) to secure top market positions (Hotelier, 2007). Green management of hospitality businesses and supply chains can also cultivate customer loyalty, shown by more visit intentions, through improving its reputation and differentiating its brand (Han et al., 2011; Jang et al., 2015).

The social dimension of sustainable hospitality supply chain management also has a positive influence on customer loyalty. The socially responsible actions towards internal and external stakeholders can increase customer loyalty. On the internal stakeholder side, socially responsible actions towards enhancing employees' welfare can positively impact employees' loyalty, which in turn creates more customer satisfaction and loyalty (Chi and Gursoy, 2009).

On the external stakeholder side, promotion of a company's social responsibility efforts and relationship management is likely to increase its reputation as a socially responsible company and likely to result in higher customer loyalty (Nikolaeva and Bicho, 2011).

Sustainability efforts with financial goals are more likely to be viewed as genuine by both internal and external stakeholders (Hunt and Morgan, 1995). Hospitality companies' good financial performance can enable them to offer better services and higher quality products, which can improve customer loyalty (Shi et al., 2014). The enhanced value perception can enable companies to reap corresponding outcomes such as a good reputation and overall image (Miles and Covin, 2000).

Hypothesis 2 The environmental, social, and economic dimensions of sustainable supply chain management in hospitality institutions have a significant positive impact on customer loyalty. 


\subsection{The Influence of Customer Satisfaction on Customer Loyalty}

Numerous previous studies report that customer satisfaction is the antecedent of loyalty (Gursoy et al., 2014). This positive link also commonly exists in the hospitality context. For example, the positive influence of customer satisfaction on customer loyalty is evident in repeat hotel stays. Studies argue that increased satisfaction by hotels' corporate reputation and perceived quality positively affects tourists' loyalty (Loureiro and Kastenholz, 2011). The positive link between customers' satisfaction with hotels and their loyalty has been solid and strong in the last several decades, no matter what the economic circumstance is (Kim et al., 2013).

Hypothesis 3 Customer satisfaction has a significant positive impact on customer loyalty.

\subsection{Study hypotheses}

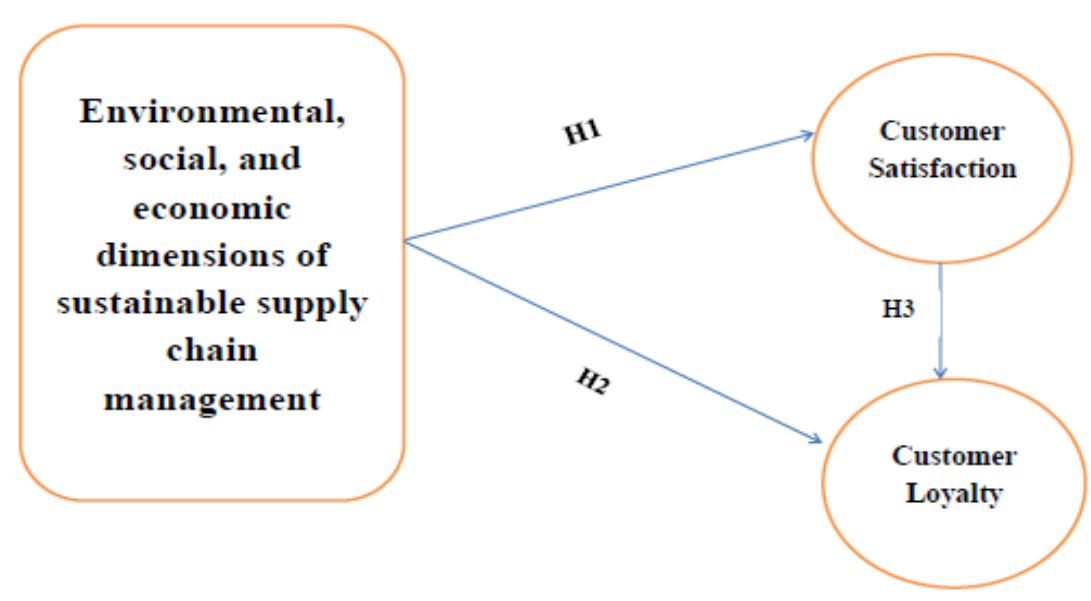

Figure 1 Research model and hypotheses

\section{Methodology}

\subsection{Research Instrument}

The questionnaire used in this study comprised four parts. Part A of the questionnaire was concerned with the demographic profile of respondents. The question in this part includes gender, age, education, marital status, and nationality. Part B measured the perception of sustainable hospitality supply chain management through three dimensions. The first dimension focused on the environmental sustainability dimension. This section included 14 
items that measured attention to the environment. The second dimension contained 13 items measuring the social sustainability dimension related to employees, consumers, communities, suppliers, and the government. The third dimension with 5 items analyses economic sustainability practices. Part C measured the respondents' satisfaction. Part D measured the respondent's loyalty.

A five-point Likert scale of the agreement was used where 1 means 'Strongly Agree',2 means 'Agree',3 'Neutral',4 'Disagree', 5 'Strongly Disagree'. A Likert scale is a "measure of a set of attitudes relating to a particular area" (Bryman,2008,P.146).

\subsection{Sample and data collection}

563 questionnaire forms were distributed to a random sample technique of customers in Five-star hotels in Cairo, while508 questionnaires were recollected with an approximate response rate of $91.2 \%$ of the total sample and were found usable for analysis.

\subsection{Data Analysis}

To achieve the objective of the study, the statistical techniques used in data analysis include Cronbach alpha to assess the reliability, Frequencies, Means, standard deviation, Spearman's correlation, and simple linear regression

\subsection{Reliability}

According to Nunnally (1987), the reliability coefficient of 0.70 or higher is considered "acceptable" in most social science research. The Cronbach Alpha reliability for variables and the test indicated that the reliability coefficient for variables was above 0.88 which indicates that the instrument is reliable for being used.

\section{Findings}

\subsection{Demographic Information}

The results in a table (1) indicate the majority of respondents were males by $54.9 \%$ of the sample; $56.1 \%$ younger than 30 years old. In terms of the educational level, there were $45.1 \%$ of respondents had a bachelor's degree; 49\% were married .Finally, there $58.5 \%$ of respondents are foreigners. 
Table (1) Demographic profile of survey respondents

\begin{tabular}{|c|c|c|}
\hline Variables & Frequencies & Percentage \\
\hline \multicolumn{3}{|c|}{ Gender } \\
\hline Male & 270 & $54.9 \%$ \\
\hline Female & 222 & $45.1 \%$ \\
\hline Total & 492 & $100 \%$ \\
\hline \multicolumn{3}{|c|}{ Age } \\
\hline Younger than 30 years & 276 & $56.1 \%$ \\
\hline 30 - less than 40 years & 54 & $11 \%$ \\
\hline 40 - less than 50 years & 96 & $19.5 \%$ \\
\hline Older than 50 years & 66 & $13.4 \%$ \\
\hline Total & 492 & $100 \%$ \\
\hline \multicolumn{3}{|c|}{ Education } \\
\hline Bachelor degree & 222 & $45.1 \%$ \\
\hline Master degree & 84 & $17.1 \%$ \\
\hline $\mathrm{PhD}$ degree & 36 & $7.3 \%$ \\
\hline Others & 150 & $30.5 \%$ \\
\hline Total & 492 & $100 \%$ \\
\hline \multicolumn{3}{|c|}{ Marital status } \\
\hline Single & 221 & $44.9 \%$ \\
\hline Married & 241 & $49 \%$ \\
\hline Divorced & 20 & $4.1 \%$ \\
\hline Widowed & 10 & $2 \%$ \\
\hline Total & 492 & $100 \%$ \\
\hline \multicolumn{3}{|c|}{ Nationality } \\
\hline Egyptian & 204 & $41.5 \%$ \\
\hline Foreigner & 288 & $58.5 \%$ \\
\hline Total & 492 & $100 \%$ \\
\hline
\end{tabular}

\subsection{Sustainable supply chain management practices}

Table (2) indicated the results of the descriptive analysis for the level of applying sustainable supply chain management practices in hotels. The results depicted that there is a medium level of applying sustainable supply chain management practices, as mean was 3.36 and the standard deviation was 1.09 .

Results in the same table depicted that the social dimension in the highest applied dimension of sustainable supply chain management, as mean was 3.49 and the standard deviation was 1.18, followed by the environmental dimension, where mean was 3.35 and 
the standard deviation was 1.10, then finally, economic dimension, as mean was 3.25 , and the standard the deviation was 1.12 .

Table (2) descriptive analysis of applying sustainable supply chain management practices

\begin{tabular}{|c|c|c|c|}
\hline & Item & Mean & SD \\
\hline ENV1 & Purchase environmentally friendly products & 3.54 & 1.12 \\
\hline ENV2 & Avoid purchasing overly packaged products & 3.23 & 1.24 \\
\hline ENV3 & Purchase organic certified food & 3.33 & 1.29 \\
\hline ENV4 & Implement an energy-saving program & 3.47 & 1.14 \\
\hline ENV5 & Use water-saving flush in bathrooms & 3.34 & 1.25 \\
\hline ENV6 & $\begin{array}{l}\text { Promote membership of environmental } \\
\text { bodies/ charities }\end{array}$ & 3.32 & 1.19 \\
\hline ENV7 & Re-use foil, paper, envelopes, and menus & 3.47 & 1.15 \\
\hline ENV8 & $\begin{array}{l}\text { Furnish rooms with environmental-friendly } \\
\text { materials }\end{array}$ & 3.50 & 1.26 \\
\hline ENV9 & Recycle cooking oil & 3.10 & 1.35 \\
\hline ENV10 & $\begin{array}{l}\text { Use recyclable packing materials or } \\
\text { containers }\end{array}$ & 3.32 & 1.10 \\
\hline ENV11 & Avoid items that are not recyclable & 3.19 & 1.04 \\
\hline ENV12 & Impleme & 3.47 & 1.23 \\
\hline ENV13 & $\begin{array}{r}\text { Reduce operating noise } \\
\text { possi }\end{array}$ & 3.30 & 1.18 \\
\hline \multirow[t]{2}{*}{ ENV14 } & Use a temperature & 3.39 & 1.14 \\
\hline & $\begin{array}{r}\text { Total mean/ Standar } \\
\text { environmental }\end{array}$ & 3.35 & 1.10 \\
\hline SOC1 & Invest in employ & 3.32 & 1.22 \\
\hline & Promote fair treatme & 3.43 & 1.15 \\
\hline SOC3 & d heal & 3.62 & 1.13 \\
\hline SOC4 & $\begin{array}{c}\text { Comply with labor legislation and employee } \\
\text { contracts }\end{array}$ & 3.34 & 1.24 \\
\hline SOC5 & Respect the rights of consumers & 3.51 & 1. \\
\hline SOC6 & Provide a safe environment for consumers & 3.58 & 1.16 \\
\hline SOC7 & Develop a fair pricing strategy & 3.60 & $\begin{array}{l}1 . \\
25\end{array}$ \\
\hline SOC8 & $\begin{array}{l}\text { Improve product quality and enhance added } \\
\text { value }\end{array}$ & 3.54 & 1.27 \\
\hline SOC9 & $\begin{array}{l}\text { Respond to complaints of all consumers } \\
\text { promptly }\end{array}$ & 3.47 & 1.11 \\
\hline SOC10 & Organize activities for the local community & 3.54 & 1.29 \\
\hline
\end{tabular}




\begin{tabular}{|c|c|c|c|}
\hline SOC11 & $\begin{array}{c}\text { Provide financial support for community } \\
\text { activities }\end{array}$ & 3.32 & $\begin{array}{c}1 . \\
05\end{array}$ \\
\hline SOC12 & $\begin{array}{c}\text { Bring social responsibility into the supply } \\
\text { chain management }\end{array}$ & 3.56 & $\begin{array}{c}1 . \\
05\end{array}$ \\
\hline SOC13 & Operate legally and ethically & 3.53 & 1.18 \\
\hline & $\begin{array}{c}\text { Total mean/ Standard deviation of the } \\
\text { social dimension }\end{array}$ & 3.49 & 1.18 \\
\hline ECO1 & High dividend payment & 3.20 & 1.18 \\
\hline ECO2 & High overall performance and success level & 3.25 & 1.23 \\
\hline ECO3 & High-profit growth & 3.21 & 1.26 \\
\hline ECO4 & Low operational cost & 3.14 & 1.28 \\
\hline ECO5 & $\begin{array}{c}\text { Special products to offer a new consumer } \\
\text { group or new market segment }\end{array}$ & 3.46 & 1. \\
\hline SSC & $\begin{array}{c}\text { Total mean/ Standard deviation of the } \\
\text { economic dimension }\end{array}$ & 3.25 & 1.12 \\
\hline & $\begin{array}{c}\text { The degree of applying sustainable supply } \\
\text { chain management practices }\end{array}$ & 3.36 & 1.09 \\
\hline
\end{tabular}

Table (3) illustrated that there was a relatively high level of consumer satisfaction among the respondents, as the mean was 3.62, and the standard deviation was 1.13 .

Table (3) descriptive analysis of the level of consumer satisfaction

\begin{tabular}{|c|c|c|c|}
\hline CONST1 & Item & Mean & SD \\
\hline CONST2 & $\begin{array}{c}\text { I will be very happy if I can stay at this } \\
\text { type of hotel }\end{array}$ & 3.79 & 1.22 \\
\hline CONST3 & $\begin{array}{c}\text { I will be very satisfied if a hotel can } \\
\text { provide such a level of service }\end{array}$ & 3.60 & 1.13 \\
\hline CONST4 & $\begin{array}{c}\text { My choice to stay in this type of hotel will } \\
\text { be a wise one }\end{array}$ & 3.52 & 1.19 \\
\hline CONST5 & $\begin{array}{c}\text { I think it would be the right thing to stay at } \\
\text { this type of hotel }\end{array}$ & 3.52 & 1.07 \\
\hline & $\begin{array}{c}\text { Total mean/ Standard deviation of } \\
\text { consumer satisfaction }\end{array}$ & 3.62 & 1.13 \\
\hline
\end{tabular}

Table (4) highlighted that there was a relatively high level of consumer satisfaction among the respondents, as the mean was 3.53, and the standard deviation was 1.20. 
Table (4) descriptive analysis of the level of consumer loyalty

\begin{tabular}{|c|c|c|c|}
\hline & Item & Mean & SD \\
\hline CONLO1 & $\begin{array}{c}\text { I will recommend this type of hotel to my } \\
\text { friends, relatives or colleagues }\end{array}$ & 3.57 & 1.27 \\
\hline CONLO2 & $\begin{array}{c}\text { I will spread positive recommendations of } \\
\text { this type of hotel to others }\end{array}$ & 3.54 & 1.12 \\
\hline CONLO3 & I will stay at this type of hotel whenever & 3.49 & 1.08 \\
\hline pONLOSsible & I will encourage others to go to this type & 3.53 & 1.22 \\
\hline & $\begin{array}{c}\text { Total hotel } \\
\text { cons Standard deviation of } \\
\text { consumer loyalty }\end{array}$ & 3.53 & 1.20 \\
\hline
\end{tabular}

\subsection{Spearman correlation analysis}

The correlation between the environmental dimension and consumer satisfaction was .706 the table also showed that there is a strong positive correlation between the environmental dimension and consumer satisfaction.

Table (5) Spearman correlation analysis

\begin{tabular}{|c|c|c|}
\hline Relation & $\begin{array}{c}\text { Correlation } \\
\text { coefficient }\end{array}$ & sig \\
\hline $\begin{array}{c}\text { The relation between the environmental } \\
\text { dimension and consumer satisfaction }\end{array}$ & $.706^{* *}$ & .000 \\
\hline $\begin{array}{c}\text { The relation between social dimension and } \\
\text { consumer satisfaction }\end{array}$ & $.742^{* *}$ & .000 \\
\hline $\begin{array}{c}\text { The relation between economic dimension } \\
\text { and consumer satisfaction }\end{array}$ & $.767^{* *}$ & .000 \\
\hline $\begin{array}{c}\text { Relation coefficient between the } \\
\text { environmental dimension and consumer } \\
\text { loyalty }\end{array}$ & $.745^{* *}$ & .000 \\
\hline $\begin{array}{c}\text { The relation between social dimension and } \\
\text { consumer loyalty }\end{array}$ & $.748^{* *}$ & .000 \\
\hline $\begin{array}{c}\text { The relation between economic dimension } \\
\text { and consumer loyalty }\end{array}$ & $.799^{* *}$ & .000 \\
\hline $\begin{array}{c}\text { Relation coefficient between consumer } \\
\text { satisfaction and consumer loyalty }\end{array}$ & $.824^{* *}$ & .000 \\
\hline
\end{tabular}




\subsection{Simple linear regression}

\subsubsection{The effect of environmental dimension on consumer satisfaction}

Consumer satisfaction $=.640+.888 \times$ environmental dimension

There was a significant and positive impact on the environmental dimension on consumer satisfaction. The value of calculated $\mathrm{F}$ was (466.058) with a significant level (0.000). The result indicates the percent of change on consumer satisfaction in which explained through the environmental dimension. It also reveals that $\mathrm{R}$ Square was (0.449) which means that the independent variable (environmental dimension) explains $44.9 \%$ of the change in the dependent variable (consumer satisfaction). This means that the environmental dimension enhances the level of consumer satisfaction by $44.9 \%$.

\subsubsection{The effect of social dimension on consumer satisfaction}

Consumer satisfaction $=.637+.854 \times$ social dimension

There was a significant and positive impact on the social dimension on consumer satisfaction. The value of calculated $\mathrm{F}$ was (478.475) with a significant level (0.000). The result highlights the percent of change on consumer satisfaction in which explained through social dimension. It also indicates that R Square was (0.494) which means that the independent variable (social dimension) explains $49.4 \%$ of the change in the dependent variable (consumer satisfaction). This means that the social dimension raises the level of consumer satisfaction by $49.4 \%$.

\subsubsection{The effect of economic dimension on consumer satisfaction}

Consumer satisfaction $=.818+.861 \times$ economic dimension

There was a significant and positive impact on the economic dimension on consumer satisfaction. The results clarify that the value of the calculated $\mathrm{F}$ was (455.558) with a significant level (0.000). The result reveals the percent of change on consumer satisfaction in which explained through economic dimension. It also depicts that $\mathrm{R}$ Square was (0.434) which means that the independent variable (economic dimension) explains $43.4 \%$ of the change in the dependent 
variable (consumer satisfaction). This means that the economic dimension increases the level of consumer satisfaction by $43.4 \%$.

\subsubsection{The effect of environmental dimension on consumer loyalty}

Consumer loyalty $=.413+.929 \times$ environmental dimension

There was a significant and positive impact on the environmental dimension on consumer loyalty. The results indicate that the value of calculated $F$ was (465.363) with a significant level (0.000). The result illustrates the percent of change on consumer loyalty in which explained through the environmental dimension. It also indicates that $\mathrm{R}$ Square was $(0.421)$ which means that the independent variable (environmental dimension) explains $42.1 \%$ of the change in the dependent variable (consumer loyalty). This means that the environmental dimension increases the level of consumer loyalty by $42.1 \%$.

\subsubsection{The effect of social dimension on consumer loyalty}

Consumer loyalty $=.354+.910 \times$ social dimension

There was a significant and positive impact on the social dimension on consumer loyalty. The results indicate that the value of calculated $F$ was (551.265) with a significant level (0.000). The result clarifies the percent of change on consumer loyalty in which explained through social dimension. It also highlights that $\mathrm{R}$ Square was (0.491) which means that the independent variable (social dimension) explains $49.1 \%$ of the change in the dependent variable (consumer loyalty). This means that the social dimension enhances the level of consumer loyalty by $49.1 \%$.

\subsubsection{The effect of economic dimension on consumer loyalty}

Consumer loyalty $=.336+.983 \times$ economic dimension

There was a significant and positive impact on the economic dimension on consumer loyalty. The results show that the value of calculated F was (587.709) with a significant level (0.000). The result reveals the percent of change on consumer loyalty in which explained through economic dimension. It also indicates that $\mathrm{R}$ Square was (0.539) which means that the independent variable (economic dimension) explains $53.9 \%$ of the change in the dependent variable 
(consumer loyalty). This means that the economic dimension enhances the level of consumer loyalty by $53.9 \%$.

\subsubsection{The effect of consumer satisfaction on consumer loyalty}

Consumer loyalty $=.477+.955 \times$ consumer satisfaction

There was a significant and positive impact on consumer satisfaction on consumer loyalty. The results indicate that the value of calculated $F$ was (555.538) with a significant level (0.000). The result indicates the percent of change on consumer loyalty in which explained through consumer satisfaction. It also indicates that $\mathrm{R}$ Square was (0.500) which means that the independent variable (consumer satisfaction) explains $50 \%$ of the change in the dependent variable (consumer loyalty). This means that consumer satisfaction increases the level of consumer loyalty by $50 \%$.

\subsection{Testing Hypothesis}

Table (6) Testing Hypothesis

\begin{tabular}{|c|c|c|}
\hline Number & Hypothesis & Result \\
\hline $\mathbf{H 1}$ & $\begin{array}{c}\text { The environmental, social, and economic } \\
\text { dimensions of the management of } \\
\text { sustainable supply chains in hospitality } \\
\text { institutions have a significant positive impact } \\
\text { on customer satisfaction. }\end{array}$ & supported \\
\hline $\mathbf{H 2}$ & $\begin{array}{c}\text { The environmental, social, and economic } \\
\text { dimensions of sustainable supply chain } \\
\text { management in hospitality institutions have a } \\
\text { significant positive impact on customer } \\
\text { loyalty. }\end{array}$ & Supported \\
\hline H3 & $\begin{array}{c}\text { Customer satisfaction has a significant } \\
\text { positive impact on customer loyalty. }\end{array}$ & Supported \\
\hline
\end{tabular}

\section{Conclusion}

This study provides a comprehensive view of the impact of hospitality businesses' actions related to each dimension of sustainable hospitality supply chain management on customers' perceptions. While both the environmental and economic dimensions actions of sustainable hospitality supply chain management have positive influences on customer satisfaction and loyalty; the social dimension action is found to have a positive influence on customer satisfaction and loyalty. 
Although this study makes significant contributions to theory and practice, it is not free of limitations. This study does not differentiate the potential differences of customers' perceptions toward different types of hospitality businesses that implement sustainable hospitality supply chain management. Different types of businesses, which can be categorized by stars, locations, ownerships, may have varying practices of sustainability practices (Han et al., 2011) and may have a different impact on customer perception. Also, various demographic characteristics of customers may moderate the influence of these impacts. Future studies can explore the potential moderating effects of customer characteristics and business type between the relationship of hospitality business' sustainable hospitality supply chain management and customer perception.

\section{References}

Abbasi, M., Nilssom F. (2012), "Themes and challenges in making supply chains environmentally sustainable", Supply Chain Management, pp. 517-530.

Assaf, A. G., Josiassen, A., \& Cvelbar, L. K. (2012). Does Triple Bottom Line reporting improve hotel performance? International Journal of Hospitality Management, 31, 596-600.

Aurier, P., \& Evrard, P. (1998). Elaboration et validation d'une échelle de mesure de la satisfaction des consommateurs", Actes du 14e'me Congre's International de l'Association Francaise de Marketing, Bordeaux, 51-72.

Bansal, P., and Mcknight, B. (2009). Looking forward, pushing back and peering sideways: analyzing the sustainability of industrial symbiosis. Journal of Supply Chain Management, 45(4); 26-37.

Berezan, O., Raab, C., Yoo, M., \& Love, C. (2013). Sustainable hotel practices and nationality: The impact on guest satisfaction and guest intention to return. International Journal of Hospitality Management, 34, 227-233.

Beske P., Land A., Seuring S. (2014), "Sustainable supply chain management practices and dynamic capabilities in the food industry: A critical analysis of the literature", International Journal of Production Economics, pp. 131-143.

Biddel, G. C., Hilary, G., \& Verdi, R. S. (2009). How does financial reporting quality relate to investment efficiency? Journal of Accounting and Economics, 48 (2-3), 112-131.

Branderburg M., Govindan K., Sarkis J., Seuring S. (2014), "Quantitative models for sustainable supply chain management: 
Developments and directions", European Journal of Operational Research, pp. 299-312.

Brown, G. (2007). Corporate social responsibility: brings limited progress on workplace safety in global supply chain. Occupational Hazards, 69(8), 16-20.

Brundtland, G. H. (1987). Report of the World Commission on environment and development: "our common future.". United Nations.

Cantallops, A. S., \& Salvi, F. (2014). New consumer behavior: A review of research on e WOM and hotels. International Journal of Hospitality Management, 36, 41-51.

Carter, C. R. and D. S. Rogers (2008). "A framework of sustainable supply chain management: moving toward new theory." International Journal of Physical Distribution \& Logistics Management 38(5): 360-387.

Cetinel, F., \& Yolal, M. (2009): Public policy and sustainable tourism in Turkey. TOURISMOS: An International Multidisciplinary Refereed Journal of Tourism, 4(3); 35-50.

Chi, C. G., \& Gursoy, D. (2009). Employee satisfaction, customer satisfaction, and financial performance: An empirical examination. International Journal of Hospitality Management, 28 (2), 245-253.

Closs, D.J., Speier, C. and Meacham, N. (2011), "Sustainability to support end-to-end value chains: the role of supply chain management", Journal of the Academy of Marketing Science, pp. 101-116.

Costen, W. M., \& Salazar, J. (2011). The Impact of training and development on employee job satisfaction, loyalty, and intent to stay in the lodging industry. Journal of Human Resources in Hospitality \& Tourism, 10(3), 273-284.

Creyer, E. H., \& Ross, W.T. (1997). The influence of firm behavior on purchase intention: do customers really care about business ethics? Journal of Consumer Marketing, 14(6), 421- 432.

CSCMP (2013). "CSCMP supply chain management definitions", availableat:http://cscmp.org/sites/default/files/user_uploads/resou rces/downloads/glossary-2013.pdf (accessed 25 December 2014).

Elkington, J. (1997). Cannibals With Forks The Triple Bottom Line of 21st Century Business. London: Capstone Publishing Limited.

Gao, Y., \& Mattila, A. S. (2014). Improving consumer satisfaction in green hotels: The roles of perceived warmth, perceived 
competence, and CSR motive. International Journal of Hospitality Management, 42, 20-31.

Guide, V. D. R., Jr., Jayaraman, V., \& Linton, J. (2003). Building contingency planning for closed-loop supply chains with product recovery. Journal of Operations Management, 21(3), 259-279.

Guo, X., Ling, L., Yang, C., Li, Z., \& Liang, L. (2013). Optimal pricing strategy based on market segmentation for service products using online reservation systems: An application to hotel rooms. International Journal of Hospitality Management, $35,274-281$.

Gursoy, D., S. Chen, J., \& G. Chi, C. (2014). Theoretical examination of destination loyalty formation. International Journal of Contemporary Hospitality Management, 26(5), 809-827.

Han, H., Hsu, L. T., \& Sheu. C. (2011). Application of the theory of planned behavior to green hotel choice: Testing the effect of environmental friendly activities. Tourism Management, 31, 325-334.

Hassini, E., Surti, C., \& Searcy, C. (2012). A literature review and a case study of sustainable supply chains with a focus on metrics. International Journal of Production Economics, 140, 69-82.

Holmes, T. J., \& Yan, R. (2012). Predicting consumers' preferences for and likely buying of local and organic produce: results of a choice experiment. Journal of Food Products Marketing, 18(5), 369-384.

Huang, Y., Song, H., Huang, G. Q., \& Lou, J. (2012). A comparative study of tourism supply chains with quantity competition. Journal of Travel Research, 51(6); 717-729.

Hunt, S. D., \& Morgan, R. M. (1995). The comparative advantage theory of competition. Journal of Marketing, 59(2), 1-15.

Jang, Y. J., Kim, W. G., \& Lee, H. Y. (2015). Coffee shop consumers' emotional attachment and loyalty to green stores: The moderating role of green consciousness. International Journal of Hospitality Management, 44, 146-156.

Jung, H. S., \& Yoon, H. H. (2013). Do employees' satisfied customers respond with an satisfactory relationship? The effects of employees' satisfaction on customers' satisfaction and loyalty in a family restaurant. International Journal of Hospitality Management, 34, 1-8.

Kassinis, G. I., \& Soteriou, A. C. (2003). Greening the service profit chain: The impact of environmental management practices. Production and Operations Management, 12(3); 386-403. 
Kim, H., Cha, J., Singh, A. J., \& Knutson, B. (2013). A longitudinal investigation to test the validity of the American customer satisfaction model in the U.S. hotel industry. International Journal of Hospitality Management, 35, 193-202.

Knorringa, P. (2009). Will consumer pressure improve working conditions in developing countries? Teaching Business \& Economics: The Journal of the Economics and Business Education Association, 13(1), 18-20.

Kothari, T., Clark, H., \& Roehl, W. S. (2005). E-Procurement: an emerging tool for the hotel supply chain management. International Journal of Hospitality Management, 24(3), 369389.

Krause, D. R., Vachon, S., and Klassen, R. D. (2009). Special Topic Forum on Sustainable Supply Chain Management: Introduction And Reflections On The Role Of Purchasing Management. Journal of Supply Chain Management, 45(4) ; 18-25.

Leaniz, D. P. M. G., \& Rodríguez, I. R. D. B. (2015). Exploring the Antecedents of Hotel Customer Loyalty: A Social Identity Perspective. Journal of Hospitality Marketing \& Management, 24(1), 1-23.

Lee, J.-S., Hsu (Jane), L.-T., Han, H., \& Kim, Y. (2010). Understanding how consumers View green hotels: how a hotel's green image can influence behavioural intentions. Journal of Sustainable Tourism, 18 (7), 901-914.

Lo, A., Wu, C., \& Tsai, H. (2015). The Impact of Service Quality on Positive Consumption Emotions in Resort and Hotel Spa Experiences. Journal of Hospitality Marketing \& Management, 24(2), 155-179.

Loureiro, S. M. C., \& Kastenholz, E. (2011). Corporate reputation, satisfaction, delight, and loyalty towards rural lodging units in Portugal. International Journal of Hospitality Management, 30, 575-583.

Luce, R. A., Barber, A. E., \& Hillman, A. J. (2001). Good deeds and misdeeds: A mediated model of the effect of corporate social performance on organizational attractiveness. Business \& Society, 40, 397-415.

Miles, M. P., \& Covin, J. C. (2000). Environmental marketing: A source of reputational, competitive and financial advantage. Journal of Business Ethics, 23, 299-311.

Nikolaeva, R., \& Bicho, M. (2011). The role of institutional and reputational factors in the voluntary adoption of corporate social 
responsibility standards. Journal of the Academy of Marketing Science, 39(1), 136-157.

Odoom, C. K. (2012). Logistics and supply chain management in the hotel industry: Impact on hotel performance in service delivery. UNLV Theses/Dissertations/Professional Papers/Capstones, paper 1339.

Paek, H. J., Kim, S., Hove, T., \& Huh, J. Y. (2013). Reduced harm or another gateway to smoking? Source, message, and information characteristics of e-cigarette videos on YouTube. Journal of health communication, 19(5), 545-560.

Prud'homme, B., \& Raymond, L. (2013). Sustainable development practices in the hospitality industry: An empirical study of their impact on customer satisfaction and intentions. International Journal of Hospitality Management, 34, 116-126.

Rahman, I., Reynolds, D. and Svaren, S. (2012), 'How 'green' are North American hotels? An exploration of low-cost adoption practices", International Journal of Hospitality Management, Vol. 31 No. 3, pp. 720-727.

Salmones, M., Crespo, A. H., \& Bosque, I. R. (2005). Influence of corporate social responsibility on loyalty and valuation of services. Journal of Business Ethics, 61:369-385.

Sanchez-Fernandez, R., \& Iniesta-Bonillo, M. A. (2009). Efficiency and quality as economic dimensions of perceived value: Conceptualization, measurement, and effect on satisfaction. Journal of Retailing and Consumer Services, 16, 425-433.

Šeri'c, M., \& Gil-Saura, I. (2012). ICT, IMC, and brand equity in high-quality hotels of Dalmatia: An analysis from guest perceptions. Journal of Hospitality Marketing \& Management, $21(8) ; 821-851$.

Seuring, S. and M. Muller (2008). "From a literature review to a conceptual framework for sustainable supply chain management." Journal of Cleaner Production 16(15): 1699-1710.

Shi, Y., Prentice, C., \& He, W., (2014). Linking service quality, customer satisfaction and loyalty in casinos, does membership matter? International Journal of Hospitality Management, 40, 8191.

Teng, C.C., Horng, J.S., Hu, M.L.M., Chien, L.H. and Shen, Y.C. (2012), "Developing energy conservation and carbon reduction indicators for the hotel industry in Taiwan", International Journal of Hospitality Management, Vol. 31 No. 1, pp. 199-208. 
Tsai, L. M. (2012). Frameworks of casino resorts supply chain. UNLV Theses/Dissertations/ Professional Papers/Capstones, paper 1356.

Tse, A. (2009). Las Vegas hoteliers lowering rates to recapture missing meetings business. Meeting News, 33(12); 35.

U.S. Travel Association, (2009). American travelers more familiar with'green travel'but unwilling to pay more to support it. Retrieved from http://www.ustravel.org/news/pressreleases/american-travelers-more-familiar-'greentravel'

Winter, M., \& Knemeyer, A. M. (2013). Exploring the integration of sustainability and supply chain management: Current state and opportunities for future inquiry. International Journal of Physical Distribution \& Logistics Management, 43(1); 18-38.

Xu., X, Gursoy, D. (2015). A conceptual framework of sustainable hospitality supply chain management. Journal of Hospitality Marketing \& Management, 24, 229-259

Zhang, X., Song, H., \& Huang, G. Q. (2009). Tourism supply chain management: A new research agenda. Tourism Management, 30(3); 345-358. 


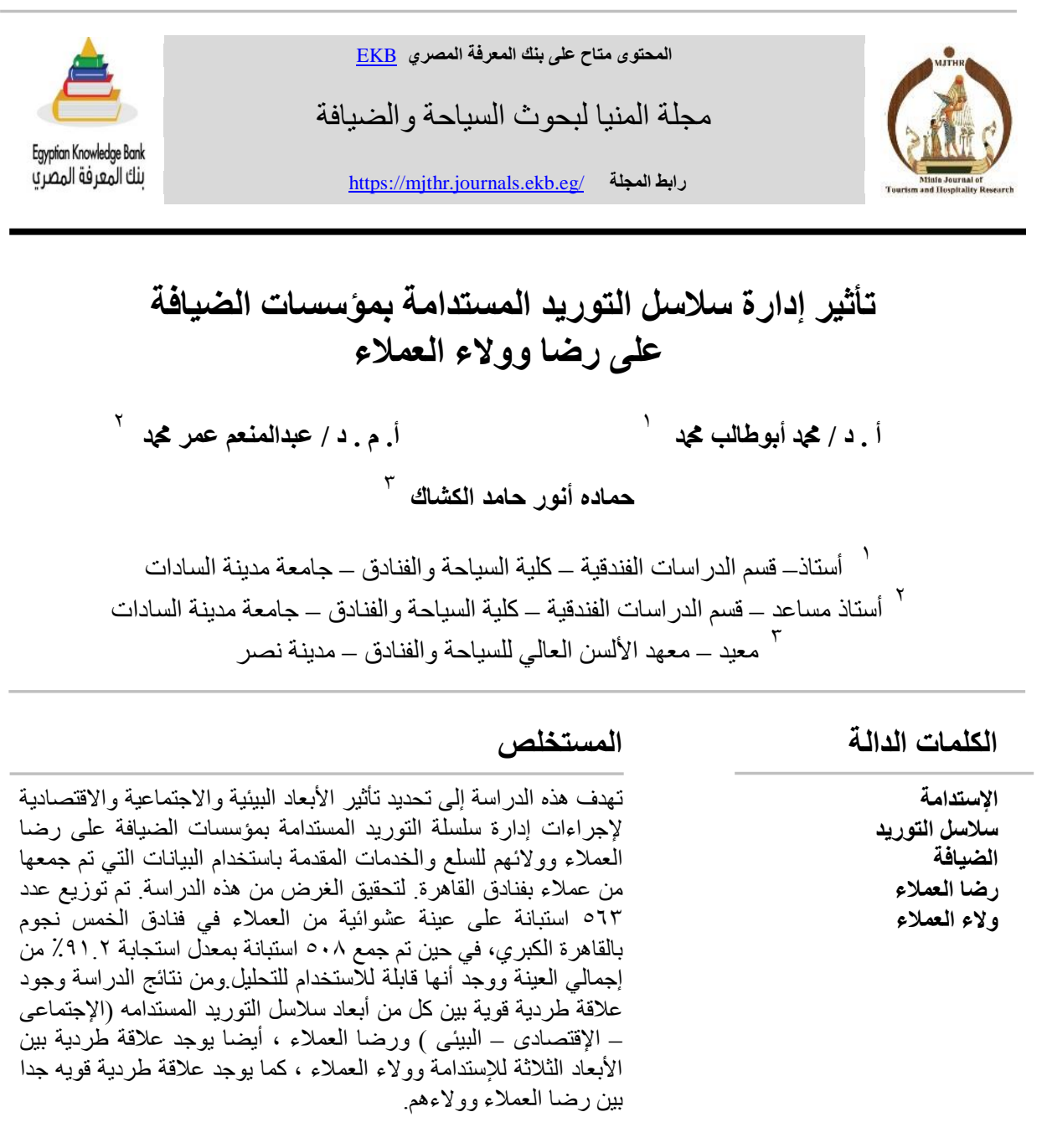

Printed ISSN 2357-0652

Online ISSN 2735-4741 